\title{
The Current State of Democracy and Democratic Governance in Mongolia
}

\author{
0. Khatanbold (M ongolia)
}

\begin{abstract}
7 he paper aimed to express that democracy development and promoting democratic governance in Mongolia brought specific

1 changes; however, difficulties and challenges. These are the process to institutionalize democracy, mainly in creating a democratic mechanism within public institutions. Failed policies, emphasis in political parties, and the election process influence democratic institution building.

While the Mongolia's democratic governance indicators initiative was very much owned by national stakeholders, an important aspect of the process was to engage with key international partners who specialize on democracy assessments. The nationally owned democratic governance indicators express multifaceted and intricate manifestations of social life, it is difficult to fully assess, and using this simplified assessment method.

The content of paper has categorized by the survey data and information such conducted by the 2009-2010 on the "Changes in the state of Mongolia's democratic governance: 2009-2010" and other initial sources in related to the democratic governance and democracy changes in Mongolia in that years.
\end{abstract}

\section{Rationale}

The State of Democracy framework is founded on a fundamental set of democratic principles and mediating values. Drawing on the rich tradition of democratic theory and efforts at defining democracy (see Landman 2005a), the fundamental principles of democracy upon which the framework is based are (1) popular control over public decision making and decision makers, and (2) equality of respect and voice between citizens in the exercise of that control. In addition to these two principles, there are seven mediating values in the framework, including participation, authorization, representation, accountability, transparency, responsiveness, and solidarity. The achievement of these mediating 
values in turn rely on a series of requirements that need to be in place and institutional means with which to realize them (Beetham, Bracking, Kearton, and Weir 2002: 14).

The reason for developing democratic governance indicators is to answer a very simple and specific question "How democratic is our country and its government?" In answering this question, one inevitably needs to base the response on the vision and principles of democracy and opportunities for their implementation in political and social practice.

The key principles of democracy are the principles of control of people and political equality. The quality of democracy is measured by the efficiency of popular control over government decision-making process, expansion of their participation in such processes, elimination of monopoly of "the upper crust" in decision making as well as capacity to overcome obstacles such as discrimination based on gender, ethnic origin, religion, language, culture and wealth. The control of people is exercised, although not directly, through their elected representatives. Since people do not exercise control over government decision-making directly, this right is exercised through control of their elected representatives. The efficiency of this control, equal opportunity to exercise such control by different groups is the main indicator of how democratic is representative democracy at national and local levels.

The control by the people and political equality are the basic principles of assessment of democratic governance. In other words, the process of government decision- making and the control exercised by the people over decision-makers, equal opportunity for citizens to exercise this control are the principles on which democracy in decision-making is evaluated. These principles and relevant indicators are shown below as follows:

- Popular participation in political process

- Law on prerogatives, legal justification

- Representative Governance

- Government Accountability

- Transparency of Activities

- Government Responsiveness

- Social Unity 
Table 1. Mediating values, requirements, and institutional means

(www.idea.int)

\begin{tabular}{|c|c|c|}
\hline $\begin{array}{l}\text { Mediating } \\
\text { values }\end{array}$ & Requirements & $\begin{array}{l}\text { Institutional means of } \\
\text { realization }\end{array}$ \\
\hline Participation & $\begin{array}{l}\text { - rights to participate } \\
\text { - capacities/resources to partici- } \\
\text { pate } \\
\text { - agencies for participation } \\
\text { - participatory culture }\end{array}$ & $\begin{array}{l}\text { - civil and political rights } \\
\text { system } \\
\text { - economic and social rights } \\
\text { - elections, parties, NGOs } \\
\text { - education for citizenship }\end{array}$ \\
\hline Authorization & $\begin{array}{l}\text { - validation of constitution } \\
\text { - choise of officeholders/pro- } \\
\text { grammes } \\
\text { - control of elected over non- } \\
\text { elected executive personnel }\end{array}$ & $\begin{array}{l}\text { - referenda } \\
\text { - free and fair elections } \\
\text { - systems of subordination to } \\
\text { elected officials }\end{array}$ \\
\hline Representation & $\begin{array}{l}\text { - legislature representative of } \\
\text { main currents of popular opin- } \\
\text { ion } \\
\text { - all public institutions represen- } \\
\text { tative of social composition of } \\
\text { electorate }\end{array}$ & $\begin{array}{l}\text { - electoral and party system } \\
\text { - anti-discrimination laws } \\
\text { - affirmative action policies }\end{array}$ \\
\hline Transparency & $\begin{array}{l}\text { - government open to legislative } \\
\text { and public scrutiny }\end{array}$ & $\begin{array}{l}\text { - freedom of information in } \\
\text { legislation } \\
\text { - independent media }\end{array}$ \\
\hline Responsiveness & $\begin{array}{l}\text { - accessibility of government to } \\
\text { electors and different sections } \\
\text { of public opninion in policy } \\
\text { formation, implementation and } \\
\text { service delivery }\end{array}$ & $\begin{array}{l}\text { - systematic \& open proce- } \\
\text { dures of public consulta- } \\
\text { tion } \\
\text { - effective legal redress } \\
\text { - local government close to } \\
\text { people }\end{array}$ \\
\hline Solidarity & $\begin{array}{l}\text { - tolerance of diversity at home } \\
\text { - support for democratic govern- } \\
\text { ments and popular democratic } \\
\text { struggles abroad }\end{array}$ & $\begin{array}{l}\text { - civic and human rights } \\
\text { education } \\
\text { - international human rights } \\
\text { law } \\
\text { - UN and other agencies } \\
\text { - International NGOs }\end{array}$ \\
\hline
\end{tabular}

The achievement of these mediating values in turn relies on a series of requirements and institutional means with which to realize them. The combination of principles and values yields four main pillars of assessment each with additional sub-categories of analysis which were used to orient the entire assessment project. 
The pillars and sub-categories of Democracy Assessment are in the following.

- Citizenship, Law and Rights

- Responsible and Accountable Government

- Civil Society and Popular Participation

- Democracy beyond the State

As the number of new and restored democracies increases, the subject of democratic governance indicators has become more complex. Several concepts of assessment and comparison of democratic governance have been developed and research data based on such concepts are becoming available to the public. The end result of these in essence is directed at assessing the quality of democracy. Although these concepts concentrate on separate issues such as human rights, assessment of governance, correlation between democracy and economic activity, state of democracy and public opinion, social and economic assessment, they are all aimed at measuring the quality of democratic governance. In the process of developing the democratic governance indicators for Mongolia, the national research team compared methodologies used by organizations such as the UNDP, the World Bank, USAID and Institute for Democracy and Electoral Assistance (International IDEA), which carry out comparative research in this field.

\section{The current state of democracy and democratic governance in Mongolia}

In particular, the work on assessing democracy and developing democratic governance indicators in Mongolia employed a series of mixed methods drawn from mainstream social, legal, and political sciences. This effort to assess the quality, depth, and breadth of the democratic experience drew on multiple sources of information and data in an attempt to 'triangulate' the democratic assessment and provide an inclusive process for democratic discussion and reform.

The first survey was conducted within the scope of the Follow-up to the Fifth International Conference of New or Restored Democracies (ICNRD-5) project jointly implemented by the Government of Mongolia (Ministry of Foreign Affairs of Mongolia) and the UNDP Mongolia, and the national research team. An important milestone of the first survey "Democratic Governance Indicators: Assessing the State of Mongolia's Governance" was produced in 2006, in regarding to make recommendations in the said report was on periodic assessments of the state of Mongolia's democratic governance to be done on a regular basis with their findings duly communicated to decisions-makers and the public at large ${ }^{1}$.

With a view to facilitating the realization of this recommendation, the national research team at the Institute of Philosophy, Sociology and Law 
of the Academy of Sciences (IPSL/AS) established a project 'Support to the implementation of Mongolia's Millennium Development Goal 9" (MDG-9) for 2007-2008, in the wake of its succesful participation in a call for project proposals by the United Nations Democracy Fund (UNDEF). One of the objectives of the project has been to establish the criteria for MDG-9, analyze the dynamics of Mongolia's democratic governance processes and evaluate the situation through a periodic assessment.

The report "Changes in the state of Mongolia's democratic governance: 2007-2008" presents the findings of this assessment carried out under the said project objective. The main units of analysis for the study have been the Mongolian legislation and the findings of a public opinion poll conducted in the spring of 2008. Based on a research methodology developed in 2005, random sampling has been used to conduct questionnare among 1,020 residents, individual interviews with 22 officials and focus group discussions involving 17 persons in 12 soums of Bulgan, Orhon, Umnugovi, Uvs and Khentii aimags as well as Ulaanbaatar districts. The quantitative and qualitative data were collected in January 2008 and their compilation and analysis were done in February 2008.

The survey on "Changes in the state of Mongolia's democratic governance: 2009-2010" highlighted changes occurred within the last years with more focus on legal environment and public opinion, as it was done in the previous surveys, instead of attempting to draw a comprehensive picture of the overall governance system. Main inputs for the survey report include national laws and legal documents, reports and information from state institutions, surveys and reports issued by researchers and from research and information NGOs, and results of the public opinion survey conducted in 2010 by researchers of the IPSL upon the request of the project team.

Methodologically, while taking account of the political and governance dynamics in Mongolia at the time of the assessment, the study relied on the basic concepts and procedures of the 2005-06 survey or, in other words, the Democracy Assessment Framework methodology of the International Institute for Democracy and Electoral Assistance (IDEA). The Mongolian version of the report provides a measurement of democratic governance using 70 core indicators and another 10 satellite indicators that highlight Mongolia's specifics ${ }^{2}$.

In brief, I would like to mention that main results and current status of the state of democracy and the specific pillars of democratic governance such developed by the nationally-led assessment achievements in compare with survey data to previous researches due to conducted in 2005, 2008 and 2010.

1. Within framework of Citizenship, Law and Rights, 429 national laws and 
145 international treaties approved by Mongolia or to which Mongolia are a party is in force 3 . Currently, "General Directions for Improving Legislation of Mongolia till 2012" approved by the State Great Hural Resolution No. 38 of May 14, 2009 is being implemented. No particular changes have been observed in knowledge and understanding of the public about basic laws between the surveys. Approximately one out of 10 respondents is not knowledgeable about basic human rights laws.

Table 2. Citizens' Knowledge of Basic Human Rights Laws ${ }^{4}$

\begin{tabular}{|l|c|c|c|c|c|c|c|c|c|}
\hline Laws & \multicolumn{3}{|c|}{ Know well } & \multicolumn{3}{c|}{ Don't know } & \multicolumn{3}{c|}{ Indicators } \\
\hline & $\mathbf{2 0 0 5}$ & $\mathbf{2 0 0 8}$ & $\mathbf{2 0 1 0}$ & $\mathbf{2 0 0 5}$ & $\mathbf{2 0 0 8}$ & $\mathbf{2 0 1 0}$ & $\mathbf{2 0 0 5}$ & $\mathbf{2 0 0 8}$ & $\mathbf{2 0 1 0}$ \\
\hline Constitution & 25.7 & 24.9 & 26.9 & 22.4 & 20.1 & 20.0 & 52 & 55 & 60.5 \\
\hline Human Rights Law & 23.3 & 18.5 & 24.6 & 23.8 & 22.4 & 24.1 & 49.5 & 45 & 50.5 \\
\hline Elections Law & 26.0 & 15.9 & 23.5 & 27.1 & 35.9 & 28.7 & 49 & 44 & 45.0 \\
\hline
\end{tabular}

The public is concerned about weak control mechanisms (21.6 percent), low accountability (16.4 percent), corruption (15.7 percent), and incompetence of civil servants (13.8 percent). More specifically, when asked what the major obstacles to enforcing the law were, 13.8 percent of respondents believed that officials themselves violated the law, 21.6 percent replied that control mechanisms were weak, 16.4 percent viewed that accountability was unsatisfactory, and 15.7 percent deemed corruption was widespread. According to the survey, negative evaluations, such as "Judiciary serves more those who have money and authority (48.3\%); An official can influence the decision-making of the judiciary $(39.9 \%)$, and "Enforcement of legal verdicts can be manipulated (25.1\%)", prevailed.

According to the survey of "Judicial Reform Index" the internationally applied methodology developed by The United States Bar Association and modified in accordance with the Mongolian context, barely 19 percent of experts "agreed" with the statement "Court decisions are respected and enforced by other branches of government", 43 percent "disagreed" and 38 percent "didn't know." ${ }^{5}$ Cross comparison of this and the State of Democratic Governance (2005 and 2008) surveys shows no positive changes in the public perception.

Most cases of civil and political rights, the violation occurs in the process of the Criminal Code application. Some amendments taken into the Criminal Code went into force in 2009. Judging by recent surveys and criminal statistics, incidents of forceful testimonies and confessions have been increasing. Moreover, methods and techniques employed during such incidents have become more sophisticated and secret. Officers get suspects 
confessed through beating, turning into emotional and psychological pressures and detaining for longer period of time ${ }^{6}$.

The following evidences of tortures and torments are present in Mongolia ${ }^{7}$ :

- Keep without food and drink for long time in order to make suspects confess in crimes;

- Prohibit sleeping and laying down;

- Kick and beat (with wooden plank or something else);

- Change suspects' cells several times, so that they could be tortured by different prisoners;

- Use electric shock;

- Keep standing up on cold stone floor for long time;

- Detain intentionally for long time without investigations;

- Put emotional and psychological pressures;

- Transfer to other camps with stricter regime;

- Use handcuffs for too long time without written record

The Human Rights Report (2010) produced by the Mongolia NGO Forum for the UN Human Rights Council underlined that a total of 139 victims of sexual exploitation have received assistance of the Gender Equality Center from 2003 to $2009 .{ }^{8} 39.1^{9}$ percent of migrants settling in the capital city outweigh the capacity of local authorities to provide basic social and economic services. The rapid population growth is followed by negative impacts such as increased workload of local kindergartens and schools. Classroom capacity at schools in suburban areas overcrowded with migrants is overloaded. Schools work in 3 shifts with $40-53^{10}$ pupils per class in each shift. The most common difficulties faced by migrants are a/issues related to registration and lengthy and bureaucratic registration processes; b/land ownership and land-related matters; c/out fashioned professions, lack of job places and being neglected in terms of employment; and $\mathrm{d} /$ financial problems.

Mongolia is a country which provides religious freedom to its citizens. There is no legal restriction for penetration and spread of other religions. Today, there are 463 entities of Buddhist, Christian, Islamic, Bahai, Shamanist and Moon religions officially registered in Mongolia, of which 50 percent is Buddhist monasteries and about 40 percent - Christian organizations and churches. ${ }^{11}$

As for the economic and social rights, the State Great Hural approved the Law of Mongolia on Human Development Fund in November 2009. Law on Unemployment Benefits payable from the Fund of Social Insurance and Law on Social Insurance were amended according to the Laws of July 16, 2009 and November 25, 2009, respectively. 
In 2009, the amount of labor force reached 1704.4 thousands and the number of economically active population - 1137.9 thousands. ${ }^{12}$ Main difficulties to getting employed include "can't find a job," "no jobs at local labor market," "lack of skills and experience," and "no one else to look after children."

Table 3. Main difficulties to getting employed

(Yearly comparisons)

\begin{tabular}{|c|c|c|c|c|c|c|c|}
\hline \multirow{2}{*}{ Subjects } & \multicolumn{2}{|c|}{2005} & \multicolumn{2}{|c|}{2008} & \multicolumn{3}{|c|}{2010} \\
\hline & 咅 & 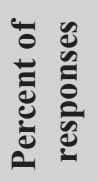 & 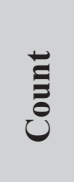 & 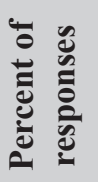 & 泀 & 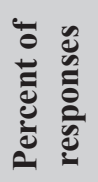 & 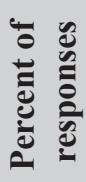 \\
\hline Family connections & 27.0 & 45.6 & 27.8 & 71.6 & 686 & 25,8 & 68,2 \\
\hline Corruption & 15.7 & 26.8 & 15.5 & 40.6 & 443 & 16,7 & 44,0 \\
\hline $\begin{array}{l}\text { Discrimination based on } \\
\text { party affiliation }\end{array}$ & 8.4 & 14.2 & 8.8 & 22.8 & 281 & 10,6 & 27,9 \\
\hline Tribal connections & - & - & - & - & 36 & 1,4 & 3,6 \\
\hline Gender discrimination & & 10.9 & 6.7 & 15.9 & 165 & 6,2 & 16,4 \\
\hline $\begin{array}{l}\text { Discrimination by age and } \\
\text { physical appearance }\end{array}$ & 21.4 & 36.2 & 22.0 & 56.4 & 484 & 18,2 & 48,1 \\
\hline $\begin{array}{l}\text { Health (physical disability } \\
\text { etc.) discrimination }\end{array}$ & - & - & - & - & 79 & 3,0 & 7,9 \\
\hline $\begin{array}{l}\text { Lack of jobs at local labor } \\
\text { market }\end{array}$ & 11.5 & 19.4 & 11.6 & 30.0 & 233 & 8,8 & 23,2 \\
\hline Unavailability of jobs & - & - & - & - & 188 & 7,1 & 18,7 \\
\hline $\begin{array}{l}\text { Outfashioned prosession/ } \\
\text { specialization }\end{array}$ & & 10.8 & & 22.8 & - & - & - \\
\hline Others & & 1.0 & 0.4 & 15.9 & 11 & 0.4 & 1.1 \\
\hline
\end{tabular}

Responses about gender discrimination (15.9:16.4), corruption (40.6:44.0), discrimination based on party affiliation (22.8:27.9) increased by $0.5-5.1$ percent from the ones in 2008 whereas responses about nepotism (71.6-68.2), discrimination by age and physical appearance (56.4:48.1), lack of jobs at local labor market (30.0:23.2) decreased by 3.4-8.3 percent.

2. Within the framework of Free and Fair Elections, Mongolia's Electoral legislation has not been changed since 2007. However, recently, an amendment 
to the Elections Law of Mongolia was submitted to the State Great Hural and it is undergoing discussion processes. In 2008, local elections and in 2009, Presidential elections were held in a legal manner and there were no significant disputes around political appointments following the elections. In the result of 2008 elections, Mongolian People's Revolutionary Party (MPRP) won 45 seats, Democratic Party - 28 seats, Citizens' Will Party - 1 seat, Citizens' Alliance - 1 seat and independent candidate -1 seat. Although the MPRP had won the majority of seats, it decided to cooperate with its biggest opposition force, the Mongolian Democratic Party and established a coalition (or unity) government.

Survey respondents explained reasons for their failure to vote in the 2005, 2008 and 2010 elections as followed. (Table 4)

Table 4. What are reasons for your failure to vote in the SGH elections?

(Years, percentage)

\begin{tabular}{|l|c|c|c|}
\hline \multicolumn{1}{|c|}{ Answers } & $\mathbf{2 0 0 5}$ & $\mathbf{2 0 0 8}$ & $\mathbf{2 0 1 0}$ \\
\hline Unfair election & 0.6 & 19.3 & 29.6 \\
\hline Lack of proper documents & 1.6 & 5.5 & 8.7 \\
\hline Lack of trust in candidates & 0.9 & 11.7 & 16.1 \\
\hline Was not given a certificate to vote & 0.6 & 2.8 & - \\
\hline Was busy at that time & 1.1 & 4.8 & - \\
\hline Was under age/ not eligible to vote & 1.6 & 27.6 & 15.1 \\
\hline Bored of politics & 0.2 & 9.0 & 6.9 \\
\hline Lack of interest & 1.2 & 15.8 & 7.9 \\
\hline Don't remember & - & 0.7 & 0.8 \\
\hline Others & - & 2.8 & 15.1 \\
\hline No answer & 10.7 & - & - \\
\hline
\end{tabular}

According to a prediction survey about voter turnout in 2012, 82.7 percent of citizens responded to the question "If elections were held tomorrow, would you participate?" - "Yes", 3.9 percent - "No" and 13.5 percent - "Don't know yet or will decide at that time." 
Table 5. What kind of electoral system is suitable for Mongolia?

(Years, percentage)

\begin{tabular}{|l|c|c|}
\hline \multicolumn{1}{|c|}{ Responses } & $\mathbf{2 0 0 8}$ & $\mathbf{2 0 1 0}$ \\
\hline Majoritarian - (one constituency, one mandate) & 20.4 & 14.6 \\
\hline $\begin{array}{l}\text { Majoritarian - extended constituency (one constituency, } \\
\text { multiple mandates) }\end{array}$ & 23.8 & 13.7 \\
\hline Mixed representation & - & 10.1 \\
\hline Proportional representation & 11.9 & 8.4 \\
\hline Don't know & 43.9 & 53.3 \\
\hline \multicolumn{1}{|c|}{ Total } & 100.0 & 100.0 \\
\hline
\end{tabular}

Researchers, political parties, citizens and voters share different opinions on what kind of electoral system is suitable for Mongolia. 18.0 percent of respondents assessed the current electoral system as being suitable for the country, 37.3 percent - unsuitable and 44.7 percent - don't know. 53.0 percent of respondents giving "unsuitable" answers believed that the incumbent system needed to be changed and 37.1 percent - "did not know."

3. Within the framework of the Democratic role of Political Parties, there were 17 political parties registered at the Supreme Court. Latterly, Mongolian People's Revolutionary Party (MPRP) changed its name into Mongolian People's Party and was registered at the Supreme Court on November 12, 2010. Following this event, in early 2011, a newly formed group called "MPRP Temporary Headquarters" has called an emergent assembly at which they announced birth of a new party and submitted its registration request to the Supreme Court. According to the result of a survey about Trust in Institutions (2010), the public identified political parties as the least trustworthy institutions in Mongolia.

Chart 1. Dynamics of Trust in Institutions ${ }^{13}$

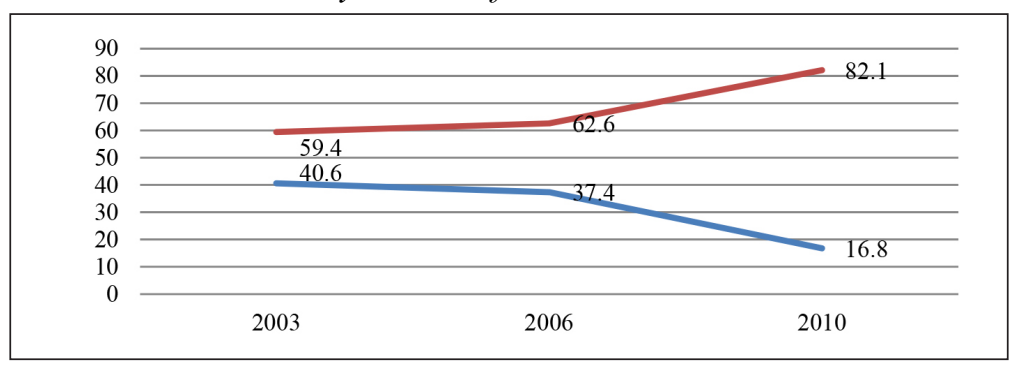


In 2010, Law on the State Great Hural was amended and specified requirements to members of the $\mathrm{SGH}$ in session periods in order to secure smooth functioning of the legislative body. At an earlier time, in 2009, Code of Ethics of SGH member was adopted.

Due to poor implementation of legal provisions regulating financing of political parties and lack of mechanisms to monitor internal practices, there is a chance for political parties to neglect the issue and keep producing false financial reports. Although an auditing practice has recently been introduced, there is no open selection for auditing companies and besides, disclosure of audit reports to the public is unsatisfactory. Disclosure of audit report is abided solely by the Democratic Party and not abided by other parties.

4. In recent years, Mongolia's economy has been intensively growing. GDP has been steadily increasing to reach MNT 3714952.9 million in 2006 and MNT 6055794.3 million in $2009^{14}$. Real GDP growth and per capita rate are summarized in Chart 3.

Yet, the relatively high economic growth rates of Mongolia have not been coupled with effective decrease in the poverty rates. "If this trend will last, it would be difficult to meet the poverty reduction goal."15

Chart 2. GDP Growth Rate, GDP per capita

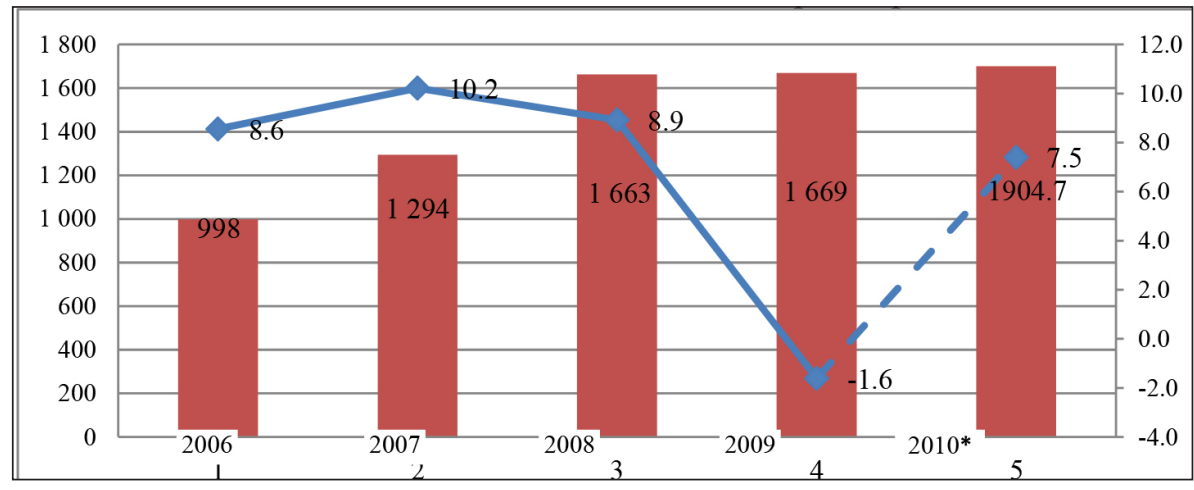

Source: Mongolia Statistical Bulletin - 2008, NSO. Ulaanbaatar, 2009, pp. 125-126. *2011 Budget Introduction, p. 2. http://www.iltod.gov.mn/wp-content/uploads/2010/10/ 2011-budget-taniltsuulga.pdf

As per WB "World Governance Indicators", governance indicators of Mongolia in 2006-2009 have been deteriorating. Specifically, indicators of "Government Effectiveness" and "Control of Corruption" have markedly decreased. 


\section{Chart 3. World Governance Indicators}

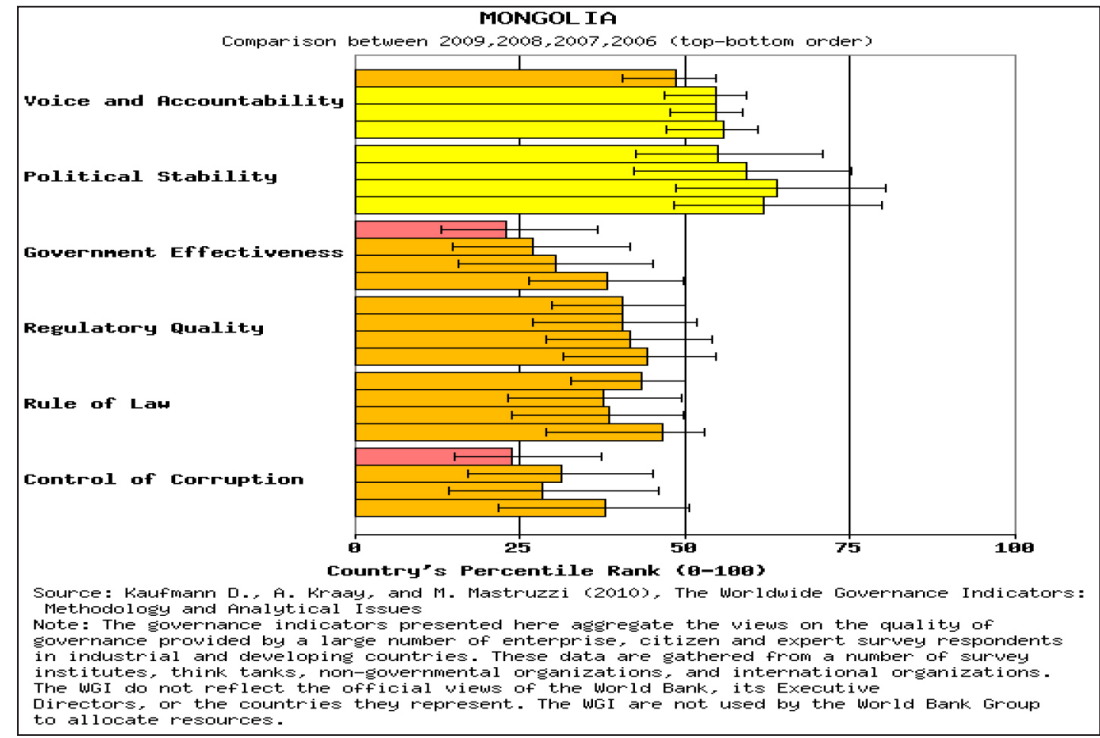

Source: Worldwide Governance Indicators (WGI) http://info.worldbank.org/governance/wgi/sc_country.asp

Since 2008, a survey entitled "Democratic Governance" has been added as a new module to the Annual Household Socio-Economic Survey conducted by the National Statistical Office and the 2008 survey encompassed 3744 citizens. Within the scope of this survey, public perception of activities of state organizations was studied. The survey respondents gave a higher satisfaction rate to social insurance and social care organizations whereas political parties and citizens' representative bodies, such as State Great Hural, Citizens' Representative Hural and Public Hural, received lower satisfaction scores.

Table 6. Public Perception of Activities of State Organizations

\begin{tabular}{|c|c|c|c|c|c|c|c|}
\hline & & \multicolumn{6}{|c|}{ Answer, percent } \\
\hline \# & Organizations & $\frac{\dot{\vec{a}}}{\dot{a}^{\circ}}$ & 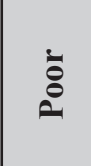 & 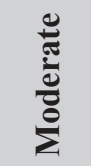 & $\begin{array}{l}\bar{O} \\
\dot{O} \\
\end{array}$ & 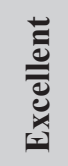 & $\overrightarrow{\bar{O}}$ \\
\hline 1 & President of Mongolia & 4,0 & 10,2 & 34,1 & 43,4 & 4,7 & 3,6 \\
\hline 2 & State Great Hural (parliament) & 10,1 & 25,9 & 45,2 & 15,1 & 0,8 & 2,9 \\
\hline
\end{tabular}




\begin{tabular}{|c|l|c|c|c|c|c|c|}
\hline 3 & Government of Mongolia & 6,9 & 18,4 & 39,7 & 28,4 & 1,9 & 4,7 \\
\hline 4 & $\begin{array}{l}\text { Citizens' Representative Hurals of } \\
\text { Capital/Aimag }\end{array}$ & 5,2 & 15,2 & 33,5 & 19,7 & 0,8 & 25,6 \\
\hline 5 & $\begin{array}{l}\text { Citizens' Representative Hurals of } \\
\text { District/Soum }\end{array}$ & 7,1 & 17,5 & 35,5 & 21,9 & 1,0 & 17,0 \\
\hline 6 & Public Hurals of Bagh/Horoo & 10,0 & 17,9 & 32,4 & 22,6 & 1,7 & 15,5 \\
\hline 7 & Governor of Capital/Aimag & 4,7 & 13,0 & 34,9 & 29,0 & 2,3 & 16,2 \\
\hline 8 & Governor of District/Soum & 6,0 & 15,7 & 35,4 & 28,9 & 2,2 & 11,8 \\
\hline 9 & Governor of Bagh/Horoo & 7,2 & 15,6 & 31,7 & 35,9 & 3,5 & 6,1 \\
\hline 10 & Supreme Court & 4,4 & 9,0 & 21,8 & 12,3 & 1,7 & 51,0 \\
\hline 11 & Court of Capital/Aimag & 3,6 & 9,8 & 23,4 & 13,4 & 1,0 & 48,9 \\
\hline 12 & Court of District/Inter-soum & 3,6 & 10,8 & 24,5 & 13,4 & 1,1 & 46,7 \\
\hline 13 & $\begin{array}{l}\text { General Authority for Implementing } \\
\text { Court Decision }\end{array}$ & 3,2 & 9,7 & 22,4 & 16,0 & 1,7 & 46,9 \\
\hline 14 & Traffic Police & 4,5 & 11,6 & 29,2 & 35,4 & 2,9 & 16,4 \\
\hline 15 & Criminal Police & 4,0 & 12,4 & 31,3 & 27,1 & 2,4 & 22,8 \\
\hline 16 & Police Patrol & 4,7 & 12,9 & 31,1 & 31,8 & 3,7 & 15,8 \\
\hline 17 & $\begin{array}{l}\text { Independent Agency Against } \\
\text { Corruption }\end{array}$ & 11,1 & 16,2 & 23,3 & 11,1 & 1,2 & 37,2 \\
\hline 18 & State Specialized Inspection Agency & 6,4 & 14,3 & 26,8 & 25,0 & 2,0 & 25,5 \\
\hline 19 & National Audit Office & 2,2 & 7,7 & 20,3 & 19,2 & 2,0 & 48,6 \\
\hline 20 & General Customs Office & 5,4 & 11,7 & 23,7 & 17,2 & 1,1 & 40,9 \\
\hline 21 & Land Authorities & 11,2 & 16,5 & 28,1 & 17,9 & 1,2 & 25,2 \\
\hline 22 & Taxation Authorities & 1,2 & 5,4 & 25,6 & 35,9 & 3,5 & 23,5 \\
\hline 23 & Social Insurance Authorities & 1,5 & 6,1 & 30,9 & 53,2 & 5,9 & 10,1 \\
\hline 24 & Social Assistance/Care Authorities & 12,3 & 30,9 & 43,6 & 5,2 & 3,6 \\
\hline 25 & Public Schools & $\begin{array}{l}1,3,4 \\
26\end{array}$ & $\begin{array}{l}\text { Public Health Organizations or } \\
\text { Hospitals }\end{array}$ & 53,7 & 7,5 & 9,3 \\
\hline & & 6,7 & 6,7 & 7,1 \\
\hline
\end{tabular}

Source: Annual Household Socio-Economic Survey,

"Democratic Governance Module”, NSO, 2009.

Issues of rights, roles and responsibilities of budget authorities and responsible officials, budget monitoring and budget relations among central and local administrative bodies were reflected in Article 151 of the General Directions for Improving Legislation of Mongolia till 2012 approved by the SGH Resolution No.38/2009. Following this spirit, Budget Law has been drafted based on principles of the Public Sector Management and Finance Law and Law on State Consolidated Budget and submitted to the SGH. 
Chart 4. Income and Expenditure of the State Consolidated Budget

\begin{tabular}{|c|c|c|c|}
\hline & 3 & \multicolumn{2}{|c|}{3} \\
\hline 2.8 & & & \\
\hline & & & \\
\hline 2006 & 2007 & 2008 & 2009 \\
\hline
\end{tabular}

Source: Statistics of the State Budget of Mongolia 2009-2010

http://www.iltod.gov.mn

The consolidated budget of Mongolia consists of the state budget, local budget, Mongolia Development Fund budget, and social insurance budget. The State budget is a budget which approved by the SGH and accumulated and administered by the Government. Income and expenditure of the state budget of Mongolia has increased threefold in the last five years. Budget expenditure growth is overwhelming GDP growth.

5. Within framework of Minimizing Corruption has been surveyed that 81.1 percent of citizens, 77.1 percent of civil servants, 79.2 percent of businessmen and 72.3 percent of experts believe that corruption is widespread in Mongolia. ${ }^{16}$ Furthermore, Mongolia control of corruption and Corruption Perceptions Index went down to 2.7 on a scale of 1 to 10 or shifted to "uncontrollable" ranking. ${ }^{17}$

Chart 5. Mongolia Annual Corruption Perception Index ${ }^{18}$

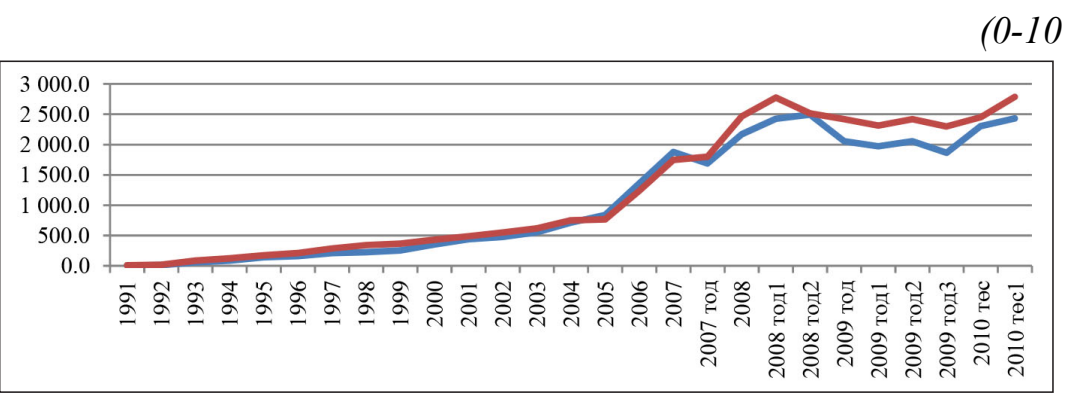

Though Mongolians have been considering corruption as one of the most problematic issues for many years, Mongolia's ranking in international corruption surveys has slightly improved. ${ }^{19}$ 
One of the effective measures to combat corruption is the collection of assets and income statements of public servants and to impose legal responsibilities on law-breakers. Collection rate of assets and income statements reached 9599 percent. ${ }^{20}$ (Chart 6).

Chart 6. Collection of Assets and Income Declaration

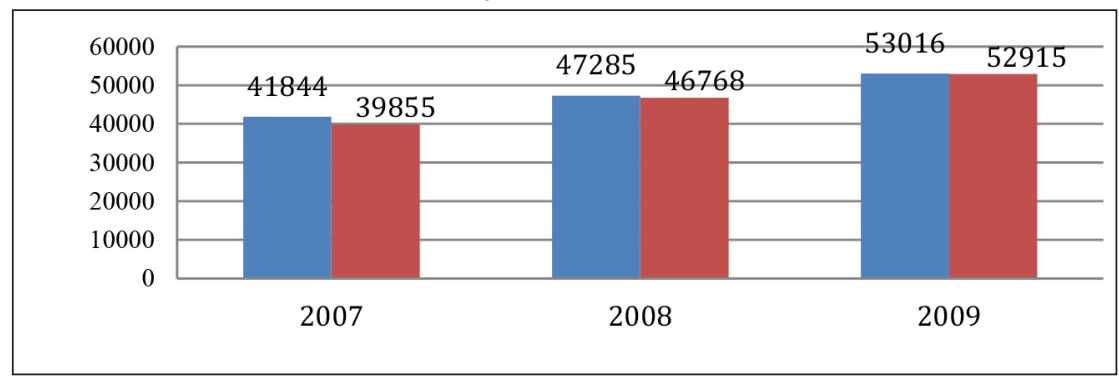

Factors hindering full control of corruption include unconformity of Mongolia's Anti-Corruption Law with the UN Anti-Corruption Convention and IAAC's disability to register and investigate all corruption-related crimes. ${ }^{21}$ Although the public evaluation of IAAC activity has changed insignificantly, the public confidence in IAAC has decreased significantly. "Global Corruption Barometer 2009" reports that state capture is perceived by the general public as a particularly serious problem in Newly Independent States and Mongolia, where more than 7 in 10 respondents claimed that bribery is often used by the private sector to shape laws and regulations. ${ }^{22}$

Experts assessed corruption in political (4.54) ${ }^{23}$, judicial and law enforcement institutions as being very high (3.92). Among judicial and law enforcement institutions, experts gave 3.49 scores to judiciary, 3.12 - to prosecutor offices, 3.50 - to the police and 3.21 - to entities implementing court decisions. More detailed results of the 2009 survey might have influenced the degree of corruption proneness of judicial and law enforcement institutions.

The dominant factors for corruption in judicial and law enforcement organizations are overlaps in activities, red tape, inefficiency, low salary and compensation of judicial officers, bad working conditions and lack of accountability and ethical mechanisms in the sector. Influences of those factors were evaluated with 4.00 scores. 
Table 7. Evaluation of factors influencing the corruption in judicial and law enforcement organizations

\begin{tabular}{|l|c|c|c|c|}
\hline \multicolumn{1}{|c|}{ Factors / influence } & $\mathbf{2 0 0 8}$ & $\mathbf{2 0 0 9}$ & $\mathbf{2 0 1 0}$ & $\begin{array}{c}\text { Variance } \\
\mathbf{( 2 0 1 0 - 2 0 0 9 )}\end{array}$ \\
\hline $\begin{array}{l}\text { Conflict of interests in decision } \\
\text { making processes of judicial and law } \\
\text { enforcement organizations }\end{array}$ & - & 3.64 & 3.75 & 0.11 \\
\hline $\begin{array}{l}\text { Lack of regulation of decision } \\
\text { making processes in judicial and law } \\
\text { enforcement organizations }\end{array}$ & - & 3.42 & 3.64 & 0.22 \\
\hline $\begin{array}{l}\text { Overlaps, red tape, inefficiency and } \\
\text { lack of controlling mechanisms } \\
\text { in judicial and law enforcement } \\
\text { organizations }\end{array}$ & - & 3.67 & 4.00 & 0.33 \\
\hline $\begin{array}{l}\text { Low salary and bad work conditions } \\
\text { in judicial and law enforcement } \\
\text { organizations }\end{array}$ & 3.64 & 4.00 & 4.00 & 0.00 \\
\hline $\begin{array}{l}\text { Absence of ethics and accountability } \\
\text { mechanism in judicial and law } \\
\text { enforcement organizations }\end{array}$ & 4.20 & 3.73 & 4.00 & 0.27 \\
\hline \multicolumn{1}{|c|}{ Average score } & $\mathbf{3 . 9 2}$ & $\mathbf{3 . 6 9}$ & $\mathbf{3 . 8 8}$ & $\mathbf{0 . 1 9}$ \\
\hline
\end{tabular}

Source: Perception of corruption in political, judicial and law enforcement institutions 2010, IAAC

6. According to the results of surveys conducted in 2005, 2008 and 2010, the NGO image in the society appears improved.

Table 8. Have NGOs been capable to carry out their roles and duties in the society?

(percent, years)

\begin{tabular}{|l|c|c|c|}
\hline \multirow{2}{*}{\multicolumn{1}{|c|}{ Answers }} & \multicolumn{3}{c|}{ Yes } \\
\cline { 2 - 4 } & $\mathbf{2 0 0 5}$ & $\mathbf{2 0 0 8}$ & $\mathbf{2 0 1 0}$ \\
\hline Expression of citizens' voice & 25,0 & 28,3 & 34,1 \\
\hline Influence on Government decisions & 17,1 & 22,6 & 25,2 \\
\hline $\begin{array}{l}\text { Influence on decisions of local } \\
\text { government }\end{array}$ & 17,7 & 13,5 & 21,6 \\
\hline Protection of public interests & 19,9 & 24,7 & 26,3 \\
\hline Protection of member interests & 31,4 & 22,7 & 26,2 \\
\hline Way of benefiting from foreign aid & 28,0 & 13,7 & 24,7 \\
\hline
\end{tabular}

Source: State of Democracy in Mongolia. Sociological Survey Report. 2010 
Only 11.7 percent of respondents in the public survey on DGIs believed that NGOs were active ("very good" and "good") in their local areas whereas 31.0 percent replied that there were no NGO activities ("bad" and "too bad"). This image has been fairly stable in last years. Although assessment of NGO activities varied by regions, in every region, one out of two respondents gave a score below average; hence, it re-affirms the mediocrity of NGO activities in Mongolia.

Oddly, the same three surveys reveal a tendency of deterioration in the NGO roles and duties. However, the number of people, who did not answer the question, has decreased and this could be viewed as an improvement of NGO public relations activities.

Chart 7. Have NGOs been capable to carry out their roles and duties in the society? (percent, years)

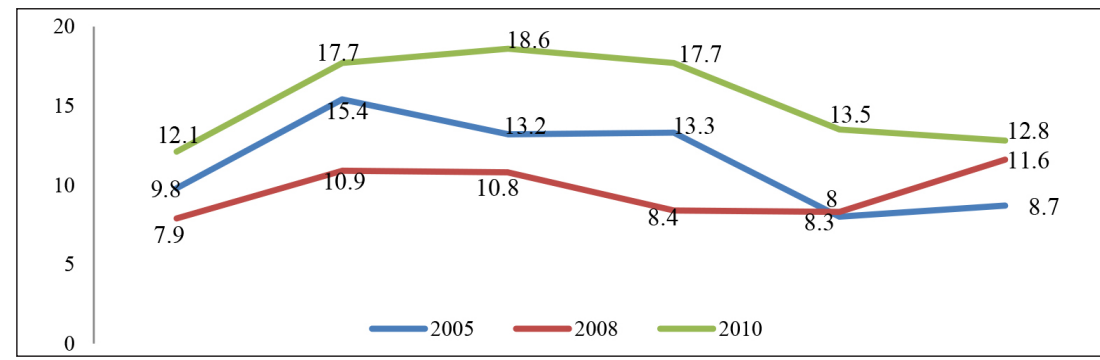

Source: State of Democracy in Mongolia. Sociological Survey Report. 2010

Result of the 2010 survey showed that 60.5 percent of the survey respondents were interested in politics at above average level and 35.0 percent replied that little bit interested or not interested.

The Global Human Development Report placed Mongolia at $94^{\text {th }}$ among 140 countries in terms of gender development index. In Mongolia, there are 76,369 disabled persons of which 46 percent is men and 54 percent - women. Though number of women at managerial positions in first-line and medium levels of administrative and support services is high, this number is low in political and special services.

7. Within framework of Government Responsiveness, that Citizen $\mathrm{Hall}^{24}$ opened in the Government House in December 2009 at the initiative of the President of Mongolia has become an effective measure to improve government decision-making through citizen input by providing a venue for regular public hearings on proposed legislation, regulations and decrees in order to arrive at decisions openly and transparently and to strengthen relationships between the state and the public. Since 2009, over 10 public 
hearings on proposed legislations and policy documents and 19 hearings on other matters have been held in the Citizen Hall in which 1643 citizens took part and proposed 376 opinions and comments. Moreover, 2182 citizens participated in 49 panel discussions. Following this practice, DarkhanUul aimag and Khan-Uul district of Ulaanbaatar city have established their Citizen Halls. An analysis of annual reports by SGH and local hural members reveals that a member visits his/her constituency from 1 to 2 times a year and meets with an average of 84 voters. ${ }^{25}$

Research findings repeatedly evince that a trend of the past years has been that of a decline of public trust in governance institutions and political parties. Judging by the public assessment about the state of governance in Mongolia, there is a general perception that Mongolia is governed by an oligarchic group.

Table 9. Public Opinion about Governance in Mongolia

\begin{tabular}{|l|l|c|c|}
\hline № & & Number & Percent \\
\hline 1 & Democratic governance is developing & 175 & 17,5 \\
\hline 2 & $\begin{array}{l}\text { There is a strong entrenchment of oligarchic } \\
\text { power. }\end{array}$ & 433 & 43,3 \\
\hline 3 & There is a governance deficit. & 89 & 8,9 \\
\hline 4 & Governance is bankrupted. & 55 & 5,5 \\
\hline 5 & Don’t know. & 248 & 24,8 \\
\hline
\end{tabular}

Source: State of Democracy in Mongolia. Sociological Survey Report. 2010

It is possible to say level of citizens' satisfaction with the public service may represent the government capacity to resolve social problems.

Table 10. How do you evaluate activities of state institutions at different levels?

\begin{tabular}{|c|c|c|c|c|c|c|c|c|}
\hline № & vel & 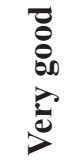 & تั & 芯 & ص్ન & $\frac{\vec{J}}{0}$ & 泀言 & 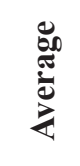 \\
\hline 1 & At Ministerial level & 2,6 & 14,4 & 45,0 & 10,6 & 2,9 & 24,5 & 3.04 \\
\hline 2 & At Agency level & 1,7 & 14,3 & 38,8 & 14,8 & 2,2 & 28,1 & 2.98 \\
\hline 3 & At Capital/Aimag level & 1,7 & 12,5 & 47,3 & 15,6 & 3,4 & 19,5 & 2.92 \\
\hline 4 & At District/Soum level & 1,3 & 14,5 & 43,5 & 17,1 & 6,3 & 17,3 & 2.85 \\
\hline 5 & At Bagh/Horoo level & 2,2 & 13,6 & 42,0 & 18,8 & 6,0 & 17,4 & 2.84 \\
\hline
\end{tabular}

Source: State of Democracy in Mongolia. Sociological Survey Report. 2010 
As studies of recent years confirmed unemployment, poverty reduction, job generation, elimination of corruption, ensuring social stability, improving economic growth, establishing justice and accountability have been primary social concerns for many years. The studies also show that there is an expectation among people that the government should take main responsibility for the resolution of these issues and a certain trust in its ability to do so.

Table 11. The public evaluation of opportunities for autonomy of local governments, 2010

\begin{tabular}{|c|l|c|c|c|c|}
\hline № & \multicolumn{1}{|c|}{ Category label } & Good & Average & Bad & $\begin{array}{c}\text { Average } \\
\text { indicator }\end{array}$ \\
\hline $\mathbf{1}$ & Budget, finance & 14,7 & $\mathbf{5 4 , 3}$ & 31 & 32,17 \\
\hline $\mathbf{2}$ & Human resources & $\mathbf{1 8 , 7}$ & $\mathbf{5 6 , 1}$ & 25,2 & 42,60 \\
\hline $\mathbf{3}$ & Decision-making on local issues & 14,2 & $\mathbf{5 4 , 7}$ & 31 & 31,42 \\
\hline $\mathbf{4}$ & Management of local resources & 10,7 & 44,7 & $\mathbf{4 4 , 6}$ & 19,35 \\
\hline $\mathbf{5}$ & Public service capacity & 12,4 & 53,2 & $\mathbf{3 4 , 4}$ & 26,50 \\
\hline $\mathbf{6}$ & Provision of information to citizens & 12,6 & 49,3 & $\mathbf{3 8 , 1}$ & 24,85 \\
\hline & & & & & $\mathbf{2 9 , 4 8}$ \\
\hline
\end{tabular}

Studies of local governments' autonomy have been presenting finance/ budget matter, human resource, decision-making, resource allocation, service delivery and public provision of information as menacing issues that need to be addressed. Average of the public's evaluation of these issues in surveyed aimags was 29,48 . This is a rather disappointing result because it means 1 in each 3 respondents sees no autonomy for local governments.

Table 12. Institutional Support to Citizens (percent), 2010

\begin{tabular}{|c|c|c|c|c|c|c|c|c|}
\hline № & & $\frac{0.00}{\frac{0}{2}}$ & 00 & 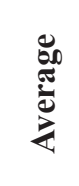 & 苛 & 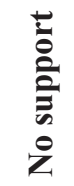 & 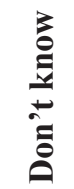 & $\sum_{\Sigma}^{\Xi}$ \\
\hline 1 & NGOs & 0,9 & 4,4 & 10,1 & 10,0 & 61,5 & 13,0 & 1.54 \\
\hline 2 & Political party fellows & 1,6 & 3,4 & 8,7 & 7,0 & 67,5 & 11,8 & 1.47 \\
\hline 3 & Civil servants & 1,2 & 3,7 & 11,8 & 10,4 & 60,8 & 12,0 & 1.57 \\
\hline 4 & Politicians, members of SGH & 0,6 & 1,6 & 6,5 & 7,9 & 69,3 & 14,0 & 1.33 \\
\hline
\end{tabular}

Source: State of Democracy in Mongolia. Sociological Survey Report. 2010 
As to the above table, citizens get a tiny little support from government and non-governmental organizations. It discloses, on one hand, the low level of public trust in those institutions, and on the other hand, the low level of citizen support and partnership initiatives of government and nongovernmental organizations.

8. Within in the framework of International Dimensions of Democracy, the growth of total exports in 2010 to MNT 2.6 billion is to be attributed primarily to the copper price hikes on international markets. In parallel with this, the volume of imports has gone up to amount to MNT 2.9 billion. Exports were up by 39.6 percent and imports-up by 39.9 percent respectively, compared to 2009. External trade balance showed a deficit in 2010. Net reserves of the Mongolian foreign-exchange climbed to a record increase of US\$ 1947.0 million or grew up by 70 percent compared to the previous year. ${ }^{27}$ Share of minerals in Mongolian exports was 35.2 percent in 2000; but, by the year of 2009, this number reached 66.4 percent and it was influenced by increase in exports of coal, zinc concentrates, iron ore and molybdenum ore in addition to copper. In total exports of 2009, the value from copper concentrates was 26,6 percent, crude and semi-processed gold $-16,4$ percent, coal - 16,2 percent, zinc ore, concentrates and crude petroleum - 6,1 percent and iron ore $-4,7$ percent. The value of the mining sector's output accounted for 50-70 percent of the total export value. Mongolia's exports heavily rely on the sole mining sector and therefore the country's economic growth is sensitive to the fluctuations in mineral resource prices. ${ }^{28}$

The partnership between Mongolia and donor governments as well as international financial institutions (World Bank, Asian Development Bank, European Bank of Reconstruction and Development, etc.) encompasses many aspects of development. While Japan's assistance ${ }^{29}$ supports the development of institutional and human capacity, infrastructure and environmental protection, aid from the World Bank and Asian Development Bank is targeted at health, education, and social protection and infrastructure sectors. Assistance from the UN specialized agencies prioritizes support to the development of civil society organizations, anti-corruption efforts, promotion of democratic governance, and resolution of health and gender issues. In recent years, the Government of Mongolia and its donor partners have heightened their attention to the issues of strategic outcomes of official development assistance, both credit and grant aid, bettering coordination between these two forms of assistance and increasing their effectiveness.

The 2010 evaluation point is higher than the 2008 one by 0.5 point and it shows a gradual progress in the conformity of Mongolian laws and regulations with international human rights treaties and conventions. ${ }^{30}$ Moreover, in two 
years, Mongolia has ratified the United Nation's Convention on the Rights of Persons with Disabilities, Protocol to Prevent, Suppress and Punish Trafficking in Persons Especially Women and Children, supplementing the United Nations Convention against Transnational Organized Crime, and Optional Protocol to the International Covenant on Economic, Social and Cultural Rights.

All member states noted that while Mongolia has joined and ratified key UN human rights conventions, it has failed to submit on a timely basis reports on the status of their implementation, based on factual information, with analysis and conclusions. They recommended that attention be focused in this direction. Member states also recommended that Mongolia join other UN conventions, in particular, the Second Optional Protocol (Death Penalty) of the International Covenant on Economic, Social and Cultural Rights (ICCPR), the Optional Protocol to the Convention against Torture, the Convention on the Protection of Rights of All Migrant Workers and Members of their Families, the Convention on Protection of Persons from Enforced Disappearance, and the Convention on the Status of Refugees. Mongolia has not become yet party to the Convention relating to the Status of Refugees. Therefore the legal framework for receiving, accommodating and releasing refugees is not in place.

Finally, in regarding to the above mentioned survey a result that reflects the findings of an evaluation done by a team of experts who applied the methodology of the 2005-2006 assessment.

Table 13. Overall assessment of Democratic Governance in Mongolia

(percent), 2010

\begin{tabular}{|c|c|c|c|}
\hline Democratic Governance Pillars & 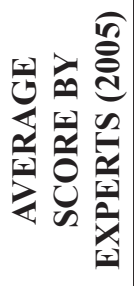 & 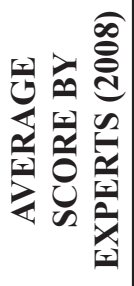 & 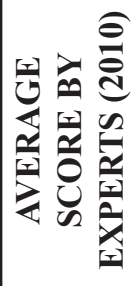 \\
\hline 1. Citizenship, Law and Rights & 2,95 & 3,4 & 3.46 \\
\hline 2. Responsible and Accountable Government & 2,64 & 2,8 & 2.69 \\
\hline 3. Civil Society and Popular Participation & 2,84 & 2,93 & 2,67 \\
\hline 4. Democracy beyond the State & 3,8 & 3,7 & 4,0 \\
\hline Overall Assessment of Democratic Governance & 3,02 & 3,0 & 3,01 \\
\hline
\end{tabular}


The state of democratic governance in Mongolia was assessed at the overall score of 3.02 (2006), 3.0 (2008), and 3.01 points in 2010. This indicates that there were a slight reverse in the democratic governance development in Mongolia; however, governance in Mongolia is still at its crossroads and can turn either way. All comparison scores are in the above table.

The results of the periodic research outcome, that the whole process established a firm link between the assessment and consolidation of democracy. Developing and collecting democratic governance indicators, carrying out mass and elite surveys, engaging in focus groups and dialogues, and organizing national events and public forums have all contributed to identifying concrete challenges and possible solutions to these challenges in an effort for bring about further consolidation of democracy in Mongolia.

The achievements of the follow-up activities thus sit squarely in the main aims and objectives of the state of democracy and democratic governance in Mongolia's initiatives to address these challenges for Strengthening Democracy, the following measures should be taken: ${ }^{31}$

- Ensure realistic power distribution, reflecting on the core concept of the constitution, through legislation.

- Pass a legislation that will increase citizen participation, as well as allowing citizens to monitor legislation process to influence decision making.

- Improve the election legal framework and systematically reform its procedure and practice.

- Strengthen national capacity through improving activities of government and non-governmental organizations working to protect human rights and ensuring freedom. Citizen legal knowledge must also be increased.

- Secure citizens' right to access information through the approval of the Law on Information Freedom. In addition, the legal environment for mass media independency and security should be improved.

- Implement national programs on citizen education to increase their political and democracy knowledge.

- Regularly conduct nationwide study on the state of human rights, democratic governance, corruption, and make them accessible to all decision makers and public. 


\section{Conclusion}

The various activities demonstrated a direct link between the assessments of democracy such as linked to the DGIs, Country Information Note, Urban Governance Indicators and Civil Society Index and the consolidation of democracy for National Plan of Action. Carrying out the activities helped build national capacity for democratic assessment and democratic reform across the different sectors and showed a remarkable degree of cooperation and understanding between state and non-state actors.

Despite the many unique features that characterise Mongolia, the follow-up activities reflect a common set of challenges faced by many new democracies, as well as many mature democracies, suggesting Mongolia joins other democracies in the world in struggling to develop long-lasting democratic institutions and to inculcate deeply felt democratic values. In addition to the general sense of cooperation at the domestic level, the follow-up activities were carried out in a spirit of international cooperation, and in many ways set a milestone in the idea of supporting democracy worldwide.

National-led democracy assessment processes linked to a sensible and concrete reform agenda provide a grounded method for consolidating democracy that involves key stakeholders and provides a sense of national ownership that is crucial for long-term democratic sustainability. 


\section{End Notes}

${ }^{1}$ MDG-9 project. UNDP. Changes in the state of Mongolia's democratic governance: 2007-2008. Research report. Ulaanbaatar, , 2008, pp. 7-10

2 MDG-9 project. UNDP. Millennium Development goal-9 indicators and The State of Democracy in Mongolia. Country statement-report. Ulaanbaatar, Mongolia, 2009, p.180

3 www.legalinfo.mn

4 Assessment Report of the Strategic Plan for Justice System of Mongolia, Judicial Reform Program, USAID (2006)

5 Brent T. White. Report on the Status of Court Reform in Mongolia, Ulaanbaatar. 2009, p. 16.

${ }^{6}$ Oyunchimeg P., Combating Tortures and Torments: Theory and Practice, Ph. D Dissertation. Ulaanbaatar. 2009. p. 2.

7 Ibid, p.146.

8 Human Trafficking and Human Rights, UPR-UNIVERSAL PERIODIC REVIEW Factsheet on Mongolia. 2010.

9 Migrants and Refugees' Rights. UPR-UNIVERSAL PERIODIC REVIEW Factsheet on Mongolia. 2010.

${ }^{10}$ Ibid.,

${ }^{11}$ National Human Rights Review (The Government Report to UN Human Rights Council). 2010. p.14.

12 Mongolia Statistical Bulletin-2009. NSO, Ulaanbaatar., 2010. p.108.

13 Political Education Academy, Survey conducted within the scope of East Asia Barometer project. 2010.

14 Mongolia Statistical Bulletin -2009, NSO, Ulaanbaatar. 2010, p.125.

15 Implementation of the Millennium Development Goals. Third Country Report. Ulaanbaatar, 2009, p.25.

${ }^{16}$ Corruption Perception Index. 2009 Report, IAAC, Ulaanbaatar, 2009., pp.123, 204, 237 and 266 (3000 citizens/households, 2000 civil servants, 1000 businessmen, 350 experts participated in the survey)

17 WB Institute. Control of Corruption. http://info.wordbank.org/ governance/wgi/sc_country.asp

18 Transparency International Survey // http://www.transparency.org/

19 Mongolia Corruption Benchmarking Survey. Asia Foundation. Ulaanbaatar. 2009. p. 5.

${ }^{20}$ IAAC Activity Report 2009, Ulaanbaatar. 2009. pp.16-17.

${ }^{21}$ An IAAC inquirer has right to investigate the following crimes specified in the Criminal Law of Mongolia. These are 263/ Abuse of power or of office by a state official 264/ Excess of authority by a state official, 
265/Abuse of authority by an official of an NGO or a business entity, 266/ Excess of authority by an official of an NGO or a business entity, 268/ Receiving of a bribe, 269/ Giving of a bribe, 270/ Intermediation in bribery, and 273/ Spending of the budget funds contrary to their designation.

22 Global Corruption Barometer 2009. Justice, Theory and Methodology Periodical. 2009. № 1. p.83.

${ }^{23}$ Experts assessed within the scale of 1-5 scores (1- no corruption at all and 5-high level of corruption).

${ }^{24} \mathrm{http}: / /$ www.president.mn/mongolian/node/185

${ }^{25} \mathrm{http}: / /$ www.gec.gov.mn/

${ }^{26}$ MDG9 Project, State of Democracy in Mongolia. Sociological Survey Report. UB., Mongolia. 2010

${ }^{27}$ Mongol Bank Information Bulletin. 2010.

${ }^{28}$ Mongolia has the least diversified economy among developing countries (37th place).

${ }^{29}$ Through JICA

30 Expert evaluation on conformity of Mongolian laws and regulations with international human rights treaties and conventions received an evaluation of 3.4 points (or above "satisfactory") out of 5 as maximum, and this indicated a need for further review of legislation for conformity.

31 MDG-9 project. Changes in the state of Mongolia's democratic governance: 2007-2008. Research report. Ulaanbaatar, Mongolia, 2008, pp. 129-131 